\title{
Missionaries of the Party: Work-team Participation and Intellectual Incorporation
}

\author{
Elizabeth J. Perry
}

\begin{abstract}
Among the most distinctive features of Chinese Communist Party governance is the frequent deployment of work teams to conduct campaigns, implement policies and troubleshoot crises. An underappreciated aspect of work-team operations from Land Reform to the present has been the active participation of educated intellectuals as key intermediaries between central leaders and grassroots society. Serving in effect as "missionaries" of the Party, intellectual work-team members function as trained "ritual specialists" in carrying out their appointed mission. Although work teams are often not the most efficient or effective means of governance, the impact of work-team experience on team members themselves is consequential. Employing quasi-religious practices designed to promote the ideological incorporation of intellectuals, work teams have helped to forestall the emergence in China of an alienated class of dissidents like those whose criticisms eroded the legitimacy of Communist regimes elsewhere in the world.
\end{abstract}

Keywords: China; work teams; intellectuals; campaign-style governance; ritual specialists; Land Reform; Thought Reform; Four Cleans; Precision Poverty Alleviation; anti-corruption

In many respects, the Chinese Communist Party (CCP) operates like any Leninist party. It controls official policy, personnel and propaganda, and supervises government agencies at all levels. Yet certain CCP practices do differ from other Leninist parties, reflecting lessons gleaned during a century of eventful experience. ${ }^{1}$ Departures from the Leninist playbook help to explain the CCP's dexterity and durability as both a revolutionary party and a ruling party.

Among the most distinctive CCP governance methods is the frequent reliance on "work teams" (gongzuodui, gongzuozu 工作队, 工作组) to conduct campaigns, implement priorities and troubleshoot crises. Work teams are ad-hoc task forces sent by higher levels of the Party and government to the

* Harvard University, Cambridge, MA, USA. Email: eperry@gov.harvard.edu.

1 Tsai, Chung and Hsu 2021; Heilmann 2018; Shue and Thornton 2017; Heilmann and Perry 2011. 
grassroots for a limited time to carry out urgent initiatives that the regular bureaucracy is deemed unable or unwilling to handle on its own. To varying degrees, work teams employ societal mobilization (in place of bureaucratic administration) to conduct their mission. Dispensing with routine procedures in favour of speed and flexibility, they display both the strengths and the weaknesses of China's signature "campaign-style governance" (yundongshi zhili 运动式治理). ${ }^{2}$ Work teams have spearheaded a series of state-mobilized campaigns in the People's Republic of China (PRC), from Mao's Land Reform to Xi's Precision Poverty Alleviation.

The origins of work teams reside in Russian and Soviet precedents plenipotentiaries, shock brigades, troikas, 25,000ers, and the like - but they assumed important new features in the Chinese context. ${ }^{3}$ In both countries, mobile units of outsiders were a primary vehicle for party-state penetration of the countryside. However, in contrast to the Soviet Union, where the task forces responsible for grain requisition and agricultural collectivization consisted overwhelmingly of urban cadres and factory workers, Chinese counterparts were made up mostly of rural cadres and peasant activists augmented by a sizeable component of educated "intellectuals" (zhishifenzi 知识分子). ${ }^{4}$ Village cadres and activists brought pragmatism and familiarity with local conditions to their assignment, while those with higher education contributed idealism and expertise. Although their educational credentials varied over time, the prestige that intellectuals enjoyed in Chinese society made them effective purveyors of Party policy. ${ }^{5}$

Innovations on the Soviet prototype in both composition and orientation helped Chinese work teams attain levels of grassroots acceptance and achievement that had eluded their Russian precursors. ${ }^{6}$ In China, as is well known, waves of work teams radically reconfigured property relations and political authority in the countryside during the Land Reform movement and collectivization. ${ }^{7}$ Equally important but less well recognized, work-team participation offered powerful incentives for urban intellectuals to disavow “bourgeois thinking” (zichan jieji sixiang 资产阶级思想) and declare allegiance to the CCP. This process has been facilitated by carefully designed training programmes. Unlike Russian collectivization brigades, which were dispatched directly from factory to village with little advance notice, members of Chinese work teams undergo weeks and even months of intensive instruction. A centrepiece of these programmes, today often conducted at Party schools, is the transmission of proven techniques of mobilization, indoctrination and selfimprovement. ${ }^{8}$ The curriculum bears an intriguing resemblance to seminary

4 Cheek 2015, 5. Chinese dictionaries define "intellectual" as an "educated person," which includes college students, professors, writers and technical experts.

5 Goldman, Cheek and Hamrin 1987; Gu and Goldman 2004.

6 Viola et al. 2003.

7 Shue 1980, 19.

8 Pieke 2010. 
classes for Christian missionaries about to be sent to the foreign mission field, which include instruction in scripture, preaching and confession as well as in practical techniques for inciting emotional enthusiasm and engagement among the target population of "converts." 9

An array of pedagogical and disciplinary measures - advance training, on-site criticism and self-criticism, check-ups by inspection teams, evaluations tied to promotion prospects - encourage work-team members to approach their service in effect as ritual specialists responsible for proper procedure and receptive to self-reflection and spiritual strengthening. The results can be compared to the lasting impact that youthful missionary activity has been found to exert in very different contexts, often drawing those who engage in the evangelizing experience into a lifetime of religious observance. ${ }^{10}$ Work teams foster the incorporation of intellectuals, helping to forestall the emergence of an alienated class of dissidents like those whose criticisms eroded the legitimacy of Communist regimes in Eastern Europe and the Soviet Union. ${ }^{11}$

Incorporation of the Chinese intelligentsia has occurred over the course of countless work-team assignments, in city and countryside alike, for a range of purposes. Ease in achieving designated objectives depends on cooperation from local authorities. Medical and crisis relief teams delivering scarce resources and expertise may be welcomed by grassroots officials, whereas teams dispatched during anti-corruption campaigns to combat cadre malfeasance often trigger fierce opposition and adopt strong-arm tactics. Yet those that encounter serious difficulties are the ones whose members are likely to report experiencing the greatest personal awakening in the course of service. Resistance from local cadres encourages closer connections to "the masses," affording team members a keener appreciation of villagers' aspirations. Grassroots bureaucratic antagonism also generates greater dependence on higher-level authorities, strengthening support for central Party goals. Again, one might point to parallels with religious proselytizing, where hostility from indigenous elites fosters missionaries' interaction and identification with the downtrodden as well as with their home mission boards, even while sometimes sparking violent confrontations on the ground. ${ }^{12}$

Like missionaries, work-team members face the difficult task of mobilizing in an unfamiliar and potentially unfriendly setting. The challenge is particularly daunting for urban-to-rural deployments, which even today comprise the lion's share of work-team assignments. Missionary and work-team manuals alike recommend house-to-house visits to learn local customs and identify likely converts based on living conditions and beliefs. ${ }^{13}$ Since Land Reform, the

13 Bliss 1897, 45-48; Beijing Party Committee 1965, 35-57. 
CCP's prescribed solution for overcoming the cultural divide separating the urban educated from the rural "masses" has been the "three togethers" (santong 三同) of living, eating and working alongside ordinary villagers. ${ }^{14}$

\section{Land Reform}

While classic accounts of Land Reform highlighted the leadership role of peasant cadres and activists, recent scholarship stresses that urban intellectuals were also "of critical importance." 15 During the Civil War period, thousands of university students and teachers from Beijing and other cities in north China assisted in the classification and redistribution of property in the Communist base areas. After the establishment of the PRC in 1949, as "old cadres" were assigned to new bureaucratic posts, urban intellectuals supplanted rural cadres as the majority membership on the hundreds of thousands of work teams deployed across the country. ${ }^{16}$

Prominent intellectuals joined work teams and follow-up investigation teams to mobilize and monitor the progress of Land Reform efforts and then, through essays in national newspapers and other public outlets, attested to their personal awakening to the plight of the peasantry and their newfound appreciation for the correctness of the Party line. Such accounts were heralded by the CCP as evidence of ideological "conversion" (zhuanbian 转变). Although it is unclear how genuine the sentiments reflected in these statements were, they indicate, in Julia Strauss's words, a "praxis of accommodation to the state's new forms of hegemony" on the part of the Chinese intelligentsia. ${ }^{17}$ Regardless of their actual beliefs, by acting "as if" they accept the legitimacy of the party-state, intellectuals' compliance strengthens regime authority. ${ }^{18}$

Persuading those with advanced education and literary skills to endorse the Party's cause was not an unanticipated by-product of Land Reform; it was a central objective of the campaign. Engagement in Land Reform was intended to convince intellectuals to shed "bourgeois" inclinations and steel themselves for revolutionary struggle, thereby solidifying support for the CCP's ambitious agenda. Brian DeMare observes that intellectuals' participation in Land Reform "dovetailed perfectly" with Thought Reform. ${ }^{19}$

Diaries, memoirs and novels written at the time suggest that work-team experience could prove transformative. Western scholars are familiar with the accounts of William Hinton and David and Isabel Crook, who drew upon participation as work-team observers to construct positive narratives of the CCP's land revolution. ${ }^{20}$ For Chinese readers, the best-selling Land Reform novels of

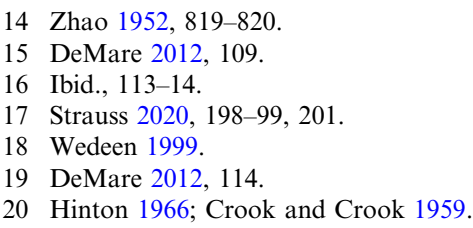


writers like Ding Ling 丁玲 and Zhou Libo 周立波 presented thinly fictionalized narratives of their own political awakening in the course of work-team service. ${ }^{21}$

Published more than half a century ago, these period pieces might simply be dismissed as romanticized reflections of the revolutionary mood of the day were it not for recent reminiscences underscoring the enduring impact of work-team participation. Even some who today express deep remorse at the excessive violence and brutality of Land Reform still credit the experience with offering valuable practice in communicating and implementing Party policy and imparting an enduring identification with Party goals. ${ }^{22}$

A striking feature of intellectuals' accounts in diaries and memoirs is the readiness with which Party and non-Party work-team members alike strove to conform to expectations of sublimation and sacrifice. Such efforts could entail serious health risks. Accustomed to campus life in the north, Beijing professors contracted a range of illnesses when subjected to the unfamiliar conditions of village life in the south of the country. ${ }^{23}$ Transplanted urbanites were not only challenged by the physical rigours of rural existence; differences in dialect and customs meant they might struggle to communicate even the most basic concepts.

To overcome such obstacles, teams were tasked with recruiting locals to assist in their efforts. Upon entering a village, teams were expected to "strike roots and forge connections" (zhagen chuanlian 扎根串连) - or deputize reliable residents (known as "roots") who could assist the team in developing relationships with other locals. These homegrown activists, in turn, were eligible for future assignments on work teams sent to neighbouring villages. Here, again, the analogy with missionary operations is instructive. A recent study points to the importance of native converts: "the literature on missionaries has ... turned its attention increasingly to the indigenes - both as targets of missionaries and as missionaries themselves." 24

In contrast to missionaries, we might expect CCP work teams to try to eradicate any expression of religious sympathies in favour of a "rational," secular understanding of class-based oppression. However, Land Reform work teams organized in 1951 under the auspices of so-called "democratic parties" (minzhu dangpai 民主党派) in Shanghai actively recruited a substantial number of Christians with the promise that their faith would not present a problem. According to a summary report, Christian team members proved especially enthusiastic practitioners of Mao's "mass line" because they regarded poor peasants as the natural focus of religious compassion. Although some had initially complained that work teams were a waste of time since land expropriation and redistribution might more efficiently be conducted by government fiat, over the course of service these sceptics came to realize that

24 Lindenfeld 2005, 328. 
the primary beneficiaries of Land Reform were not the poor peasants but themselves. One Christian work-team member was quoted as saying, "a month in the countryside taught me more than several years of education in America." 25

Besides enlisting religious adherents, work teams employed quasi-religious methods that, like many efforts at social mobilization, blur the distinction between the sacred and the secular. ${ }^{26}$ While scholarship on social movements has acknowledged the importance of religious-like beliefs and practices in inspiring ostensibly secular movements, its primary focus has centred either on the charismatic leader (messiah) or on ordinary followers (true believers), with little attention paid to those who mediate between them. Educated members of Land Reform work teams, (including many who were not themselves religious), in addition to communicating Party policies, clarifying class status and compiling official records, served as intermediary ritual specialists who directed the impassioned “speak-bitterness" ( $s u k u$ 诉苦) denunciations that constituted a central element of struggle sessions. At these assemblies, poor peasants, selected and schooled by the work team, publicly condemned those who had aggrieved them in the past. The goal was not simply to disempower landlords; it was also to "make over" (fanshen 翻身) their accusers, rendering the peasantry reborn by the act of openly voicing longstanding injustices. The emotional scene resembled a Christian tent revival, with hundreds and thousands of spectators moved to tears by the stirring testimonies. ${ }^{27}$

The origins of this quasi-religious ritual are obscure. ${ }^{28}$ In the early years of revolutionary struggle, the CCP employed speak-bitterness techniques at its night schools as an initial step in organizing peasant associations. ${ }^{29}$ Zhang Guotao 张国奉, a founding member of the CCP, recalled such methods being used in the 1920s to win over a diverse constituency of "potential converts," as he referred to them: peasants, opium-smoking bandits, disgruntled conscripts in the Kuomintang (KMT) armies, old-time KMT supporters, uninvolved bystanders and idealistic intellectuals. ${ }^{30}$ The practice of speaking bitterness does not seem to have figured in the Russian Revolution, however, and the original inspiration for this dramaturgical mode of mobilization is unclear. ${ }^{31}$ The striking similarity to Christian testimonies, in which new converts chronicle their personal journey from suffering to salvation, suggests the possibility of foreign missionary influence. Several important early Communist organizers had been educated at mission schools. For example, Yun Daiying 恽代英 studied at Hua Chung 华中, an inter-denominational Christian university in Wuchang 武昌, and participated actively in the Chinese YMCA before becoming a leader

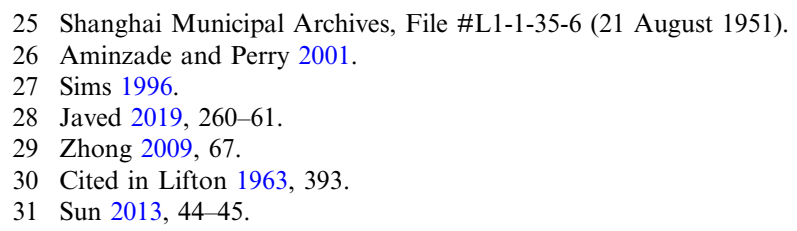


of the Communist Youth League. Diary entries during his college years make clear that Christianity, along with other Western religious currents of the day, contributed to Yun's evolving understanding of revolutionary mobilization. ${ }^{32}$ While a student, he translated into Chinese The Inner Consciousness, a how-to manual for dealing with sub-conscious emotions by William Walker Atkinson, a pioneer of the quasi-Christian "New thought" movement in early 20th-century North America. In phrases evocative of CCP techniques of speaking bitterness and Thought Reform, Atkinson emphasizes that it is possible to "make-over" oneself by replacing existing "mental material" with the "right kind" of thinking. ${ }^{33}$ Sermons delivered in Wuchang churches by Christian missionaries also made a powerful impression on Yun. But the evidence for missionary origins of speak-bitterness rituals remains circumstantial. What is certain is that after the Yan'an Rectification Movement (Yan'an zhengfeng 延安整风), when the CCP first targeted intellectuals for thought reform, speaking bitterness was adopted by Communist work teams across north China. ${ }^{34}$ In the wartime base areas, the practice was praised as the essential "sparkplug" of revolution. ${ }^{35}$

In preparing speak-bitterness rituals, work teams were responsible for identifying appropriate "masters of bitterness" (kuzhu 苦主) among villagers who had suffered at the hands of landlords and other "enemies of the people." According to archival accounts, these lead accusers sometimes underwent a seemingly miraculous healing process during their cathartic denunciations. In Hebei, for example, a peasant driven mad by his landlord's relentless mistreatment reportedly regained his sanity as soon as he publicly vented his spleen. Another "master of bitterness" who had been severely crippled by landlord beatings was suddenly able to walk again. ${ }^{36}$ While we may well doubt the veracity of these apparently apocryphal recoveries, the work-team accounts are quite convincing in portraying the act of speaking bitterness as an electrifying and emotionally liberating experience similar to faith healing at a religious revival. ${ }^{37}$

Contributing to the religious aura of the occasion was the practice of combining speak-bitterness denunciations with funeral ceremonies. A People's Liberation Army (PLA) work-team manual prescribed the combination as an effective means for converting former KMT soldiers to the Communist side. Surviving relatives of recently deceased villagers, after placing spirit tablets, flowers and other sacrificial items on a makeshift altar to honour the dead, would "pour out their bitterness" to the accompaniment of mourning music and incense. The denunciations were followed by a mass oath-swearing ceremony in which all present raised their fists in front of the "spirit altar" and pledged eternal

32 Yun 1981, 94-95, 125, 136-37.

33 Atkinson 1908, 39-40.

34 Gao 2019; Hebei Provincial Archives 1990, 230-32.

35 Hebei Provincial Archives 1990, 98.

36 Ibid., 125.

37 Kidd 2009. 
loyalty to the revolutionary cause. ${ }^{38}$ In a manner reminiscent of Triad secret-society initiation rites, the PLA manual prescribed the drinking of "unity wine" (qixin jiu 齐心酒) to solidify the commitment of new recruits; a rooster would be sacrificed, its blood mixed with wine, and the concoction passed around for all to imbibe. While this "superstitious" ritual was rationalized as a response to "spontaneous" mass demands, it was acknowledged to have a "profound effect" in convincing previously reluctant participants to plunge wholeheartedly into the revolutionary effort. ${ }^{39}$

The job of casting and choreographing speak-bitterness performances often fell to intellectual members of work teams. Yang Hansheng 阳翰笙, a prominent playwright who headed a Land Reform work team in Guangxi province in 1951 and 1952, convened a meeting of several fellow team members - all professors from Beijing - to determine how to conduct their first struggle session. After some discussion, the group decided to combine a "public tribunal" (gongshen 公审) with a mourning ceremony (jiling 祭灵), a format which had been introduced to them during their pre-deployment training programme in Beijing as an effective means of mass mobilization. First, they erected a large altar in an empty field to display the hundred or so spirit tablets of recently deceased villagers. At the event itself, which drew thousands of participants, ordinary peasants opened the proceedings with sorrowful funeral incantations for their late relatives, after which designated "masters of bitterness" launched strident denunciations against those held culpable for the deaths: Japanese and KMT soldiers, bandits, landlords, and the like. As an officiate, Yang Hansheng was also expected to speak. He wrote in his diary that evening, "when I thought of the many who had died under such horrible circumstances, I was seized with emotion. I couldn't help but address the audience of four or five thousand in a thundering voice, calling on them to avenge the wrongs." 40 In the end, the crowd - whipped into a frenzy by the proceedings - demanded that three local "tyrants" be executed on the spot. The goal of the struggle meeting, Yang reflected, was not just to terrify landlords and deter resistance but also to educate peasants in their own awesome power. Moreover, the process of preparing and conducting such convocations served to edify the ritual specialists themselves. Yang noted that "hearing these poor, long suffering peasants speak bitterness made me feel sad and angry. The meeting not only educated the peasants but also deeply educated me. Speaking bitterness gave me a 'baptism' (xili 洗礼) in class struggle."41 Testing and toughening China's intellectuals through grassroots service as "missionaries of the Party" was a key objective and outcome of Land Reform.

41 Ibid., 480, 488-492, 512. 


\section{Thought Reform}

The incorporation of intellectuals in this period went beyond their participation on Land Reform work teams. Before and after deployment, intellectuals were themselves subject to interrogation, humiliation and (if sufficiently contrite) eventual absolution at the hands of Thought Reform work teams dispatched to their campuses. Thought Reform work teams (composed of faculty members at other universities as well as cadres from higher-level government agencies) convened assemblies at which professors were expected to publicly confess and renounce their "bourgeois" mentality. The process called for "taking a bath" (xizao 洗澡), or submitting to public criticism, and "laying down burdens" (fangxia baofu 放下包䘞), or banishing impure thoughts. While the injunction to let go of one's encumbrances drew on a talk in which Mao urged Party cadres in Yan'an to "lay down burdens" to get close to the masses and make fewer mistakes in their work, the phrase had obvious religious overtones. ${ }^{42}$ In both Christian and Buddhist scripture, the expression is used to emphasize that conversion involves expunging improper thoughts and desires to enable a new life of spiritual commitment.

The bathing metaphor, which had also been employed during Yan'an Rectification, is of course itself replete with religious connotation - from Christian baptism to the washing of the Buddha. ${ }^{43}$ The distinguished Sino-Indian scholar, Ji Xianlin 季羡林, recalled of his experience during the Thought Reform campaign at Peking University:

At that time, public investigation of one's thoughts was called "taking a bath." Baths were taken in small, medium or large tubs. As a department chair, I had to bathe in a medium-sized tub, which meant a public interrogation at a meeting of all the students and faculty in the department. Because I had not incurred popular indignation, I did not merit a "big tub" (dapen 大盆); in other words, I was not subjected to an all-campus assembly. ${ }^{44}$

The process was a searing one, nonetheless. Ji likened his experience to the painful yet purifying catharsis of a Christian confession:

In the medium-sized tub, the water was still extremely hot. Everyone spoke with unusual intensity, some from heartfelt conviction and others less so. This was the first time in my life that I had undergone this sort of trial. Each word felt like a sharp arrow piercing my soul. It was as though I had become a Christian convert, filled with a conviction of "original sin" (yuanzui 原罪), and the more intense the accusations grew the more relaxed I felt. I became so relaxed that my whole body was covered in sweat, as if the bath were a Turkish steam bath. When in the end those assembled agreed that I had passed muster, I was moved to the point of actually shedding tears. It seemed that my bourgeois thoughts truly had been washed away. ${ }^{45}$

Ji's "bath" left him feeling spiritually cleansed and emotionally invigorated, elated that he was now licensed to assume higher leadership responsibilities at the university. 46

$46 \mathrm{Hu}$, Guangli, and Liang 2006, 12. 
Renowned literature scholar Wu Mi 吴宓, who had been educated at Harvard thirty years before, reacted less positively to Thought Reform. But Wu also compared the process to a religious experience. After witnessing an all-campus assembly at his university in which students who had graduated from Christian schools and were versed in the practice of confession and repentance had been chosen to lead off in denouncing US imperialism, Wu wrote in his diary: "I've come to realize that this method is similar to 17 th and 18 th century Christian revival meetings in Europe and America ... The methods resemble those of Christians in many respects, but the goals and spirit are opposite." A few months later, $\mathrm{Wu}$ refined the analogy, likening the CCP's draconian imposition of discipline to the suffocating strictures of the English Puritans. ${ }^{47}$ In contrast to most of his colleagues, Wu Mi rejected the Party's demands for a public speech proclaiming his "conversion" to the Communist cause. Eventually, however, he succumbed to pressure to compose an essay attesting to a change of heart. Wu's diary records his dismay upon learning that his Thought Reform essay had been translated into English and broadcast to the United States. ${ }^{48}$

$\mathrm{Wu}$ Mi's principled resistance to the political campaigns of the day was exceptional. For many of his colleagues, work teams offered an avenue of upward mobility in the harsh and uncertain environment of the newly established PRC. In the Republican era, Chinese intellectuals had regarded overseas study in the US and Europe as the appropriate "gilding" ( jindu 金镀) needed for future academic success; now participation in Party-mandated campaigns replaced study abroad in burnishing one's résumé. ${ }^{49}$ The result was widespread compliance, although the motives were often complex. When Fudan University's distinguished historical geographer Tan Qixiang 谭其骧 summed up his Land Reform work-team experience at a Thought Reform meeting convened shortly after his return to campus, he underscored the conflicting "petty bourgeois" sentiments behind his enthusiastic enlistment:

Although I eagerly signed up for Land Reform, my reasons at the time weren't entirely correct. On the one hand, I was filled with petty bourgeois progressivism ... I felt I should participate in a political campaign in the countryside to reform myself ... I thought it was a huge honour to participate in this major political campaign as a work-team member ... I hoped to attain a bit of merit by doing my bit for the Party and new society ... Having never lived in a rural village and being unfamiliar with the peasantry, I could improve my knowledge by participating in Land Reform. On the other hand, I was filled with petty bourgeois backwardness ... I thought that since the Party and school leaders had asked me to go, I had to comply ... In order to “pass muster" (guoguan 过关), I figured one had to participate in political campaigns and go down to the countryside. ${ }^{50}$

After Tan's death, two notebooks were found among his personal effects. They contained his handwritten transcription of the Thought Reform campaign as it

50 Ge 1997, 182-83. 
unfolded in the Fudan history department in 1952. Alluding to the religious atmosphere that infused the campaign, Tan had entitled his collection "Pious confessions" (qiancheng de chanhui 虔诚的忓悔). ${ }^{51}$

The receptivity of Chinese intellectuals to Thought Reform - unlike their counterparts in the Soviet Union and Eastern Europe, it has been argued ${ }^{52}$ rendered their work-team participation of considerable value to the Communist Party. Not only were many intellectuals susceptible to quasi-religious appeals but they also proved adept at applying these approaches to others. A few years later, intellectual members of work teams in the "Four Cleans" campaign would combine the struggle techniques used against "class enemies" in Land Reform with ideological conversion methods directed against themselves in Thought Reform to fashion an extraordinarily powerful tool of political transformation and control.

\section{Four Cleans Campaign}

In the early 1960s, the CCP unleashed another massive wave of work teams to shake up the rural power structure. This time the main targets were not landlords and tyrants from the "old society," but local cadres accused of misappropriating the fruits of Land Reform, embezzling collective funds and engaging in other forms of corruption. Coming on the heels of the Great Leap Forward, when tens of millions of peasants died of starvation, the "Four Cleans" campaign (also known as the Socialist Education Movement) took aim at village and township officials suspected of having engaged in illegal practices to shield themselves and their families from the famine..$^{53}$

Four Cleans work teams enrolled more than three and a half million members. While most were higher-level cadres, virtually every college and university upperclassman in the country also enlisted, as did their professors. Before being sent down to the grassroots, team members typically underwent one to two months of intensive training. An important component of the training programme was a procedure known as "triple investigation" (sancha 三查) in which the background, outlook and behaviour of work-team candidates were scrutinized to determine whether they were qualified for deployment, much as many churches screen prospective missionaries prior to commissioning them for service. As part of the vetting, Four Cleans trainees were required to "speak bitterness" to demonstrate loyalty to the CCP; those who vented anger over the suffering caused by the Great Leap Famine were deemed unfit to serve until they received additional "education." Instruction and evaluation of work-team members continued while on assignment through interim training sessions convened at the commune or county seat. From start to finish,

53 Thornton 2007, Ch. 6 and 7. 
work-team members were reminded that the disciplinary objectives of the campaign were intended as much for themselves as for errant grassroots officials. ${ }^{54}$

Following the Land Reform pattern of "striking roots and forging connections," Four Cleans work teams tapped local "roots" for struggle sessions in which ordinary peasants "spoke bitterness" against cadres accused of corruption. In the tradition of Thought Reform, the Four Cleans also featured emotional public confessions known as "taking a bath" - or admitting one's transgressions and pledging to make amends. But now it was grassroots Party and government officials, rather than intellectuals, who were required to purify their thinking. Like the Great Awakening in 18th-century North America, these rituals were designed to "inaugurate a life-transforming encounter of spiritual focus and authority" for old and new believers alike. ${ }^{55}$ In this case, however, the object of faith was Mao Zedong Thought and the Chinese Communist Party (rather than Christianity and the Church). In both movements, the trope of baptism with past sins figuratively "washed away" to enable a future of dedication and devotion for true believers - was central.

Whereas Land Reform work teams had moved from site to site, the Four Cleans teams usually spent many months "squatting on a point" (dundian 蹲点) to carry out the "three togethers" alongside ordinary villagers (or workers and students in the case of teams sent to factories and schools.) Regardless of institutional setting, as ritual specialists responsible for ensuring proper procedure, intellectual members of work teams tended to be less forgiving than their higher-level cadre colleagues of local leaders' shortcomings. Lacking first-hand governance experience, intellectuals could be harsh critics of even the most minor infractions by grassroots officials..$^{56}$

Unlike Land Reform, where work-team members had themselves mounted the stage to speak bitterness against landlords and other class enemies, accusers in Four Cleans struggle sessions were usually restricted to local villagers. ${ }^{57} \mathrm{But}$ work teams still played a key role in coaching "masters of bitterness" for denunciations against grassroots cadres. In addition to orchestrating the criticism of corrupt cadres, an important work-team responsibility was to organize study sessions and public recitations of Mao's essays and speeches. The events were typically held in an improvised "cultural centre" - a simple structure repurposed from an existing building or hastily constructed from scratch. A portrait of Chairman Mao was reverently hung on the wall and copies of Mao's selected works were placed on the shelves. ${ }^{58}$ The function of this space was to facilitate "great conversions" (dazhuanbian 大转变) during which ordinary people's attitudes and behaviour would be transformed en masse through collective recitals of Mao's hallowed words. ${ }^{59}$

\footnotetext{
54 Liu 2009, 18-19, 22, 49.

55 Kidd 2016, 207.

56 Wang 2016, 8; Hinton 1966.

57 Luonan County Macheng Work Team 1966, 13-16.

58 Xiyu Commune Four Cleans Movement Congress 2012, 80.

59 Guangdong Provincial Party Committee 1966, 8.
} 
The Four Cleans performed a valuable service for regime durability in shifting blame for the Great Leap debacle away from top Party leaders, shielding the actual architects of the deadly disaster by scapegoating grassroots officials. ${ }^{60}$ The effects of dispatching work-team "missionaries" to bolster the legitimacy of Party Central at the expense of local cadres long outlived the post-Leap recovery; even today, a deficit of popular trust towards lower-level officials is offset by a remarkable degree of support for central authorities. $^{61}$

Work teams provide an important channel of direct communication between ordinary people and higher levels of the state. Central leaders gain access to useful information unfiltered by the bureaucratic apparatus, while citizens are reminded of the Party's abiding concern for them. Intellectuals facilitate both functions. At times when the leadership is deeply divided, however, work teams reporting to a rival political faction can be perceived as threatening. When the Four Cleans morphed into the Cultural Revolution in 1965 and 1966, Liu Shaoqi's 刘少奇 massive dispatch of work teams to restive factories and universities led Mao Zedong to call an abrupt halt to their deployment. ${ }^{62}$

\section{Post-Mao Work Teams}

Mao's moratorium notwithstanding, work teams remained an important instrument in the PRC's governance toolkit. Work teams by another name ("Mao Thought propaganda teams") reappeared later in the Cultural Revolution to demobilize Red Guards and restore order. Post-Mao China saw expanded use of work teams, from the draconian family planning efforts of the 1980s and 1990s to Xi Jinping's 习近平 signature anti-corruption and anti-poverty campaigns. ${ }^{63}$ Unlike the Mao era, when university students and faculty comprised the majority of "intellectual" participants, today's team members represent a wider range of work units whose personnel departments tap them on the basis of technical expertise. ${ }^{64}$ Even so, universities supply a disproportionate share of "first secretaries" (diyi shuji 第一书记) who serve as work-team leaders. ${ }^{65}$

60 Liu 2009, 38.

61 Tang 2016.

62 Mao 1965, 209.

63 White 2006.

64 A typical 32-person poverty-alleviation work team in south-west China included 17 graduates of polytechnic institutes, 8 university graduates, 3 advanced graduate-degree holders, and 4 members with only a high-school degree. Deng, Wang and Liu 2020.

65 In 2015, the Central Organization Department of the CCP and the Poverty Alleviation Office of the State Council jointly announced the "first secretary" programme - work team leaders with overall responsibility for political propaganda, Party building and poverty relief in a designated village. By the end of 2018, nearly 500,000 such individuals (drawn from the ranks of young university faculty and government cadres) had been appointed. The average age was 37; about half had advanced graduate degrees. See "Diyi shuji zhuli xiangcun zhenxing" (First secretaries assist rural revival). Renmin ribao, 4 December 2018, 17. 
Under $\mathrm{Xi}$, the combined use of stationary implementation teams (deployed for several years at a single site) and mobile inspection teams (which move suddenly and secretively from place to place) contributes to a pervasive climate of pressure and insecurity among grassroots bureaucrats. Local cadres complain openly about the teams' unrealistic expectations and unpredictable operations. Yet work-team members themselves are apt to express admiration for the Party's agenda and appreciation for the opportunity to advance it. Interviews in 2019 with dozens of young faculty members seconded by their universities to be "first secretaries" of work teams stationed in impoverished villages in Yunnan and Guizhou indicate a sincere, often impassioned, commitment to the Party's mission of modernizing the countryside. ${ }^{66}$ Although "first secretaries" grumble about the strain of prolonged separation from families and familiar surroundings, compounded by the need to adapt to "backward" rural conditions, they generally affirm the long-term value of the experience both for their host villages and for themselves.

Not everyone is equally earnest or enthusiastic, of course. Stationary work teams are deployed for several years at a time, and team members are usually forbidden to return home even for major holidays. Besides missing friends and family, they worry that their original work unit may overlook them for future promotions unless they keep in touch by returning regularly. ${ }^{67}$ In some places, local governments resort to surveillance cameras and facial recognition software to assist in identifying and apprehending team members who attempt to desert hardship posts in favour of frequent home visits. ${ }^{68}$

The availability of advanced digital technology obviously distinguishes today's campaigns from Maoist predecessors. A prominent feature of the anti-poverty campaign is the compilation of electronic databases to track the progress of each targeted household in "doffing the hat of poverty" (tuopin zhaimao 脱贫 摘帽). But modernized operations incorporate older repertoires as well. One Hubei county presents its anti-poverty work as creatively combining Mao's "mass line" (beneficiary households are determined "democratically" at all-village "town halls") with reliance on "big data" (unannounced inspection teams are dispatched covertly from the county level on the basis of computational analytics) ${ }^{69}$

In language redolent of the Mao era, the anti-poverty campaign calls on work-team members to "fully mobilize the activism of the impoverished masses" so that they become "masters of their own fate." 70 To carry out this mission, work teams should "squat on a point" and practise the "three togethers" so as

66 Author's interviews arranged by Fudan University in spring 2019 at poverty-stricken villages in Dali, Lijiang and Lugu Lake in Yunnan; and in Guiyang, Zunyi and Maotai in Guizhou.

67 Zhang, Yihan 2018.

68 Interview with anti-poverty cadre in Hangzhou, May 2019.

69 Zhang, Chengshuang 2017, 10.

70 Lin 2018. 
to "strike roots" and "forge connections."71 One might expect that these throwbacks to earlier revolutionary rhetoric would strike today's digitally savvy young intellectuals as anachronistic and alienating. Yet few work-team members seem to find analogies to Mao-era practices off-putting. On the contrary, they take evident inspiration from the notion that they are perpetuating the CCP's century-old tradition of mass mobilization, seeing themselves as the latest in a long line of Party propagandists. When pressed as to why he appeared so upbeat about the arduous task of attempting to modernize a distant and destitute village, one "first secretary" in Guizhou replied (with no prompting from the interviewer) that his feelings were like those of a Christian missionary trying to win over reluctant converts - despite disappointing setbacks, there was a deeper satisfaction from contributing to a sacred cause. ${ }^{72}$

It is not clear how much the deployment of work teams contributes to the elimination of poverty in the Chinese countryside. One study predicts that targeted villages will revert to pre-campaign conditions as soon as work teams are withdrawn. ${ }^{73}$ In other prioritized policy realms, such as reducing air pollution, repeated waves of (short-term) inspection teams have failed to bring about sustained improvement. ${ }^{74}$ For many governance goals, strengthening local bureaucratic administration is surely a more effective strategy than dispatching work teams. Focusing only on observable metrics of mission completion may, however, underestimate the political significance of work-team deployment. If we evaluate work teams less in terms of objective quantifiable results than in terms of subjective impact on team participants, we may reach a rather different assessment of their long-term consequences.

\section{Conclusion}

The enthusiasm that intellectuals in many countries initially displayed for communism was a critical factor in its early 20th-century rise, just as their subsequent disillusionment played a key part in its late 20th-century demise. ${ }^{75}$ There are, of course, many reasons why the Chinese Communist Party has outlasted its European counterparts, but among the most important has been the ability of the CCP to retain the allegiance of its best educated citizens. Despite vicious attacks on intellectuals in the Rectification Movement of 19411942, the Anti-Rightist Campaign of 1957, and the Cultural Revolution decade of 1966-1976, as well as continued state censorship throughout the post-Mao period, intellectuals have generally opted for incorporation over alienation. In the more than thirty years since the Tiananmen uprising of 1989, although China has seen an explosion of popular protest among nearly all sectors of society, those with higher education have, by and large, remained quiescent.

75 Brown 2009. 
The CCP has achieved this remarkable feat through a variety of initiatives, including massive state investment in universities and think tanks, attractive rewards for academic research that serves Party interests, and strategic co-optation of social-service activism, in addition to more overtly coercive means. ${ }^{76}$

Since its inception, the CCP has also sought to utilize intellectual expertise and enthusiasm by commissioning those with advanced education to assist in governing society. From writers and professors during Land Reform to university students and faculty in the Four Cleans to technical experts today, intellectuals have played a prominent role in carrying the Party's message to the grassroots. Early patterns owed much to Soviet inspiration and example, but by the 1940s, the CCP had developed distinctive repertories of work-team deployment that assigned intellectuals a far more salient role than was the case with Russian precursors. Inclusion in a series of ambitious campaigns to remake Chinese society has occurred under conditions that foster pride in one's contribution to the Party's goals, tempered by recognition of one's own shortcomings. Like self-righteous missionaries dedicated to a sacred cause yet humbled by the example of exalted saints and martyrs who preceded them, work-team members have proven to be devoted evangelists for the Party.

Organization theorists have identified the "missionary" organization - also termed the "cadre" organization - as an important alternative to Weber's ideal type of rational-legal bureaucracy. ${ }^{77}$ In the missionary model, agents are guided less by impartial rules and professional standards than by ideological or policy concerns born of intense socialization and ethical instruction. In contrast to Weberian bureaucracies, missionary organizations are intended to transform the beliefs and commitments of the ordinary people among whom they minister. Equally significant, they are designed to strengthen dedication to the Church's mission among the evangelists themselves.

The double-edged power of the missionary organization derives from the philosophical assumptions of the pedagogical system in which it is embedded. Terry Lautz, commenting on the lasting influence of the US student volunteer missionary movement in early 20th-century China, writes, "The missionary experience was formative for Americans and Chinese alike, partly because they shared the belief that education should produce moral leadership."78

A study of CCP work teams enhances our understanding of the missionary model by highlighting the catalytic role of intellectual intermediaries. Societal mobilization is widely recognized as a hallmark of CCP governance, in contrast to the tightly controlled top-down approach of most ruling Leninist parties. Less often acknowledged is the critical function of "moral leadership" - in the person of idealistic intellectuals serving as ritual specialists who convey proper policy and practice to the grassroots and in the process legitimize Party rule. As Eddy 
U observes, the relationship between Chinese communism and the intellectual has been "mutually constitutive." 79 Take, for instance, the prominent Peking University professor, Yue Daiyun 乐黛云, who served faithfully on Land Reform and Four Cleans work teams both before and after her harsh expulsion from the Party as a "rightist" in 1958. Despite having been disgraced and sentenced to labour reform, when offered a chance to re-enter the CCP in 1979, she readily accepted: "even as I recalled the disappointments of my own life and the tragic loss of my friends, I realized that some flame still burned in my heart ... I would join in the efforts to rebuild the Party, convinced that it alone could lead China forward." 80

Work-team participation is not the only means by which the educated are incorporated into the governance structure of the Communist party-state. Control over both teaching and research at institutions of higher education is a key pillar of the PRC's multifaceted "stability maintenance" regime. ${ }^{81}$ Chinese universities, especially elite universities, boast high levels of Party membership. Joining the Communist Party, Daniel Koss notes, "signifies readiness to compromise with the state." 82 Accommodation to the state's priorities by CCP members is seen today not only among young faculty members designated as "first secretaries" on anti-poverty work teams. New college graduates seeking careers as Party and government cadres volunteer for assignment to the remote countryside as "university student village officials" (daxuesheng cunguan 大学生 村官), serving as temporary aides to local cadres in hopes of rising rapidly through the bureaucratic ranks. ${ }^{83}$

Founded in 1921 by two of China's foremost intellectuals, the dean and librarian of Peking University, the Chinese Communist Party has long understood the contributions that those with higher education could make towards advancing its ambitions. Over time, through trial and error, and at considerable cost, the Party developed protocols for cultivating and deploying intellectuals as "missionaries" to the hinterland. The process entailed repeated regimens of training, monitoring and discipline to ensure faithful execution of Party projects. Although today's work-team members possess technical expertise and employ cutting-edge digital methods that their forebears could hardly have imagined, they perpetuate a dynamic tradition of societal mobilization and governance that has helped to sustain the CCP for the past century. As with other large-scale proselytizing movements, including the US Protestant effort abroad, in the end the most influential and enduring impact of the undertaking may be on the side of the missionaries and their own intellectual circles more than among their intended "converts." ${ }^{4}$

79 U 2019, xv.

80 Yue and Wakeman 1985, 387.

81 Wang, Yuhua, and Minzner 2015; Yan 2014.

82 Koss 2018, 15.

83 He and Wang 2017.

84 David Hollinger (2017) argues that the 19th-20th century foreign missionary effort exerted a critical influence on North American intellectuals, even as the number of overseas converts fell short of expectations. 


\section{Acknowledgements}

My thanks go to Zelda Zhao of the Harvard government department for help with research and with translating the abstract, and to Ma Xiaohe of the Harvard-Yenching Library for assistance in obtaining primary sources. I am also grateful to members of the Chinese politics workshops at Harvard University and the University of Michigan for their helpful suggestions on earlier drafts.

\section{Conflicts of interest}

None.

\section{Biographical note}

Elizabeth J. PERRY is Henry Rosovsky professor of government at Harvard University and director of the Harvard-Yenching Institute. Her research focuses on the history of the Chinese revolution and its implications for contemporary Chinese politics. A fellow of the American Academy of Arts and Sciences and a corresponding fellow of the British Academy, Professor Perry is the author or editor of more than 20 books including, most recently, Mao's Invisible Hand: The Political Foundations of Adaptive Governance in China (Harvard, 2011); Anyuan: Mining China's Revolutionary Tradition (California, 2012); What is the Best Kind of History? (Zhejiang, 2015); Beyond Regimes: China and India Compared (Harvard, 2018); Similar yet Different: Case Studies of China's Modern Christian Colleges (Zhejiang, 2019); and Ruling by Other Means: State-Mobilized Movements (Cambridge, 2020). Her book, Shanghai on Strike: The Politics of Chinese Labor (Stanford, 1993), received the John King Fairbank Prize of the American Historical Association; her article, "Chinese conceptions of 'rights': from Mencius to Mao - and now" (Perspectives on Politics, 2008), received the Heinz I. Eulau Prize of the American Political Science Association.

摘要: 频繁部署工作队 (组) 来推行运动、落实政策和管控危机是中共最 具特色的治理手段之一。对于从土地改革至今仍在运作的工作队机制, 有 关知识分子在其中的积极参与并未被充分探讨, 而他们是联结中央领导与 基层社会的关键中间人。作为工作队队员的知识分子, 实际上充当了党的 “传教士” 角色, 他们在完成指定任务的过程中发挥了“礼教专家” 的作 用。尽管工作队机制常常不是最有效的治理方式, 但是参与工作队的经历 往往对队员自身有着巨大的影响。为了加强对知识分子在意识形态上的吸 纳融合, 工作队制定、采取了很多准宗教式的行为规范, 这些做法有效防 止了一个与政权相背离的异见分子阶层在中国出现。而在世界其他地方, 这些异见人士的批判动摇了共产党政权的合法性根基。

关键词: 中国; 工作队; 土地改革; 知识分子; 思想改造; 四清运动; 运动式治 理; 精准扶贫; 反腐败; 礼教专家 


\section{References}

Aminzade, Ronald R., and Elizabeth J. Perry. 2001. "The sacred, religious and secular in contentious politics.” In Ronald R. Aminzade, Jack A. Goldstone, Doug McAdam, Elizabeth J. Perry, William H. Sewell, Jr., Sidney Tarrow and Charles Tilly (eds.), Silence and Voice in the Study of Contentious Politics. Cambridge: Cambridge University Press, 155-178.

Atkinson, William Watkins. 1908. The Inner Consciousness. Chicago: Advanced Thought Publishing Company.

Beijing Party Committee. 1965. Siqing gongzuodui shouce (Handbook for Four Cleans Work Teams). Beijing: Zhonggong Beijing shiwei bangongting.

Bliss, Edwin Munsell. 1897. Organization and Methods of Mission Work. New York: Fleming H. Revell.

Bozoki, Andras (ed.). 1999. Intellectuals and Politics in Central Europe. Budapest: Central European University Press.

Brown, Archie. 2009. The Rise and Fall of Communism. New York: Ecco.

Cell, Charles P. 1977. Revolution at Work: Mobilization Campaigns in China. New York: Academic Press.

Cheek, Timothy. 2015. The Intellectual in Modern Chinese History. Cambridge: Cambridge University Press.

Crook, David, and Isabel Crook. 1959. Revolution in a Chinese Village. Abingdon: Routledge and Kegan Paul Ltd.

DeMare, Brian James. 2012. "Their stinking airs: Chinese intellectuals and land reform, 1946-52." The China Journal 67, 109-130.

Deng, Yanhua, Yingyi Wang and Wei Liu. 2020. "Fupin xin jizhi: zhucun bangfu gongzuodui de zuzhi, yunzuo yu gongneng" (New anti-poverty mechanism: organization, operations and functions of village-stationed work teams). Shehuixue yanjiu 6, 44-66.

Ding, Ling. 1954. The Sun Shines over the Sangkan River. Peking: Foreign Languages Press.

Feng, Zhifeng. 2007. "Zhongguo yundongshi zhili de dingyi jiqi tezheng” (Definition and characteristics of China's campaign-style governance). Zhonggong Yinchuan shiwei dangxiao xuebao 9(2), 29-35.

Gao, Hua. 2019. How the Red Sun Rose. Hong Kong: Chinese University Press.

Ge, Jianxiong (ed.). 1997. Tan Qixiang qianzhuan (Tan Qixiang Prequel). Shanghai: Huadong shifan daxue chubanshe.

Goldman, Merle, Timothy Cheek and Carol Lee Hamrin (eds.). 1987. China's Intellectuals and the State. Cambridge, MA: Harvard University Press.

$\mathrm{Gu}$, Edward, and Merle Goldman (eds.). 2004. Chinese Intellectuals between State and Market. London: Routledge.

Guangdong Provincial Party Committee (ed.). 1966. "Guangdong shengwei guanyu zai siqing yundong huoxue huoyong Mao zhuxi zhuzuo qingkuang de baogao" (Guangdong Provincial Party Committee situation report on the Four Cleans campaign's active learning and active use of Chairman Mao's works). Hebei siqing tongxun 143(28 February), 1-11. Internal circulation document.

He, Guojun, and Shaoda Wang. 2017. "Do college graduates serving as village officials help rural China?" American Economic Journal 9(4), 186-215.

Hebei Provincial Archives (ed.). 1990. Hebei tudi gaige dang'an shiliao xuanbian (Selected Historical Archives of Hebei's Land Reform). Shijiazhuang: Hebei renmin chubanshe.

Heilmann, Sebastian. 2018. Red Swan: How Unorthodox Policy-making Facilitated China's Rise. Hong Kong: The Chinese University Press.

Heilmann, Sebastian, and Elizabeth J. Perry (eds.). 2011. Mao's Invisible Hand: The Political Foundations of Adaptive Governance in China. Cambridge, MA: Harvard University Press.

Hinton, William. 1966. Fanshen: A Documentary of Revolution in a Chinese Village. New York: Monthly Review Press. 
Hollinger, David. A. 2017. Protestants Abroad: How Missionaries Tried to Change the World but Changed America. Princeton, NJ: Princeton University Press.

Honeycutt, Roy L. 1989. "Training missionaries through the cooperative program." Baptist History and Heritage 24(4), 25-26.

$\mathrm{Hu}$, Guangli, and Zhigang Liang (eds.). 2006. Ji Xianlin huiyi wenji (Collection of Ji Xianlin's Reminiscences). Harbin: Harbin chubanshe.

Hu, Qiaomu. 1942. "Jiaotiao yu kuzi" (Dogma and trousers). Jiefang ribao, 9 March.

Hunt, Nancy Rose. 2016. A Nervous State: Violence, Remedies, and Reverie in Colonial Congo. Durham, NC: Duke University Press.

Javed, Jeffrey. 2019. "Speaking bitterness." In Christian Sorace, Ivan Franceschini and Nicholas Loubere (eds.), Afterlives of Chinese Communism: Political Concepts from Mao to Xi. Canberra: Australian National University Press, 257-261.

Joppke, Christian. 1995. East German Dissidents and the Revolution of 1989. New York: New York University Press.

Karplus, Valerie J., and Mengying Wu. 2020. "Crackdowns in hierarchies: evidence from China's environmental inspections.” MIT Sloan Research Paper No. 5700-19.

Kidd, Thomas S. 2009. The Great Awakening: The Roots of Evangelical Christianity in Colonial America. New Haven: Yale University Press.

Kidd, Thomas S. 2016. American Colonial History: Clashing Cultures and Faiths. New Haven, CT: Yale University Press.

Koss, Daniel. 2018. Where the Party Rules: The Rank and File of China's Communist State. Cambridge: Cambridge University Press.

Lautz, Terrill E. 2009. "The SVM and transformation of the Protestant mission to China." In Daniel H. Bays and Ellen Widmer (eds.), China's Christian Colleges. Stanford, CA: Stanford University Press, 3-26.

Liang, Zhigang, and Guangli Hu. 2013. Ji Xianlin zhuan (Biography of Ji Xianlin). Harbin: Harbin Press.

Lifton, Robert Jay. 1963. Thought Reform and the Psychology of Totalism. New York: W.W. Norton and Company.

Lin, Caihong. 2018. "Nongcun jingzhun fupin yundong jizhi fenxi" (Analysis of the mechanism of village precision poverty alleviation). Hezuo jingji yu keji 592(September), 190-92.

Lindenfeld, David. 2005. "Indigenous encounters with Christian missionaries in China and West Africa, 1800-1920." Journal of World History 16(3), 327-369.

Liu, Yanwen. 2009. "Siqing gongzuodui gongzuo jizhi yanjiu" (Study of the Operations of Four Cleans Work Teams). MA diss., Renmin University, Beijing.

Luo, Xinghan. 2014. "Guanyu jingzhun fupin wenti de dundian baogao" (Report on precision poverty alleviation issues while squatting on a point). Fupin wenti 15, 66-69.

Luonan County Macheng Work Team. 1966. "Pipan Liu Yonghou dengren de dahui shi zenyang zhunbei de" (How the mass meeting to criticize Liu Yonghou and others was organized). In Hebei siqing tongxun, 3 March (144), 12-16. Internal circulation document.

Mao, Zedong. 1944. "Xuexi he shiju" (Our study and the current situation), 12 April. Reprinted in 1953 Mao Zedong xuanji (Selected works of Mao Zedong), Vol. 3. Beijing: Renmin chubanshe.

Mao, Zedong. 1965. "Guanyu siqing yundong de yici jianghua" (A talk about the Four Cleans movement), 3 January. In Mao Zedong sixiang wansui (Long Live Mao Zedong Thought) Vol. 5, Doc. 140, https://www.marxists.org/chinese/maozedong/1968/. Accessed 22 December 2018.

Melton, Brian S. 2017. "The Impact of Missionary Service." PhD diss., George Mason University.

Mintzberg, Henry. 1978. The Structuring of Organizations. Englewood Cliffs, NJ: Prentice-Hall.

Perry, Elizabeth J. 2019. "Making communism work." Comparative Studies in Society and History 61 (3), 535-562.

Perry, Elizabeth J. 2020. "Educated acquiescence: how academia sustains authoritarianism in China." Theory and Society 49, 1-22. 
Pieke, Frank N. 2010. The Good Communist: Elite Training and State Building in Today's China. Cambridge: Cambridge University Press.

Political Department of Jinchaji Military Region (ed.). 1947. Suku fuchou (Speak Bitterness, Wreak Revenge).

Rothstein, Bo. 2015. "The Chinese paradox of high growth and low quality of government." Governance: An International Journal of Policy, Administration and Institutions 28(4), 533-548.

Shue, Vivienne. 1980. Peasant China in Transition: The Dynamics of Development towards Socialism, 1949-1956. Berkeley, CA: University of California Press.

Shue, Vivienne, and Patricia M. Thornton (eds.). 2017. To Govern China: Evolving Practices of Power. Cambridge: Cambridge University Press.

Sims, Patsy. 1996. Somebody Shout Amen! Inside the Tents and Tabernacles of American Revivalists. Lexington, KY: University Press of Kentucky.

St. John, Burton (ed.). 1920. North American Students and World Advance. New York: Student Volunteer Movement for Foreign Missions.

Strauss, Julia C. 2020. State Formation in China and Taiwan: Bureaucracy, Campaign and Performance. Cambridge: Cambridge University Press.

Sun, Feiyu. 2013. Social Suffering and Political Confession. Beijing: World Scientific Publications.

Tan, Qixiang. 1998. Tan Qixiang riji (Diary of Tan Qixiang). Shanghai: Wenhui chubanshe.

Tang, Wenfang. 2016. Populist Authoritarianism: Chinese Political Culture and Regime Sustainability. New York: Oxford University Press.

Thornton, Patricia M. 2007. Disciplining the State: Virtue, Violence and State-making in Modern China. Cambridge, MA: Harvard University Press.

Tsai, Kellee S., Chun-chih Chang and Szu-chien Hsu (eds.). 2021. Evolutionary Governance in China: State-Society Relations under Authoritarianism. Cambridge, MA: Harvard University Press.

U, Eddy. 2019. Creating the Intellectual: Chinese Communism and the Rise of a Classification. Berkeley, CA: University of California Press.

Underwood, Elizabeth. 2003. Challenged Identities: North American Missionaries in Korea, 18841934. Seoul: Royal Asiatic Society.

Viola, Lynne, V.P. Danilov, N.A. Ivnitskii and Denis Kozlov (eds.). 2003. The War Against the Peasantry, 1927-1930: The Tragedy of the Soviet Countryside. New Haven, CT: Yale University Press.

Wang, Haiguang. 2016. Taoyuan jingyan yanjiu ( $A$ Study of the Peach Garden Experience). Proceedings of the Fifth Workshop on Contemporary Chinese History, East China Normal University, Shanghai.

Wang, Yuhua, and Carl Minzner. 2015. "The rise of the Chinese security state." The China Quarterly 222, 339-359.

Wedeen, Lisa. 1999. Ambiguities of Domination: Politics, Rhetoric and Symbols in Contemporary Syria. Chicago: University of Chicago Press.

White, Tyrene. 2006. China's Longest Campaign: Birth Planning in the People's Republic, 1949-2005. Ithaca, NY: Cornell University Press.

Wu, Jiang. 2012. Zhengzhi cangsang liushi nian (Sixty Years of Political Turmoil). Hong Kong: Xianggang zhongwen daxue chubanshe.

Wu, Mi. 2006. Wu Mi riji xubian (Wu Mi’s Diary Sequel). Beijing: Sanlian shudian.

Wu, Zhongjie. n.d. Fudan wangshi (Past events at Fudan). Unpublished manuscript.

Xiyu Commune Four Cleans Movement Congress. 2012. "Xiyu gongshe siqing yundong daibiaohui jilu" (Minutes of Xiyu Commune Four Cleans Movement Congress). In Zhongguo dangdai minjian shiliao jikan (Documentary Series of Contemporary Chinese Popular History), No. 8. Shanghai.

Yan, Xiaojun. 2014. "Engineering stability: authoritarian political control over university students in post-Deng China." The China Quarterly 218, 493-513.

Yang, Hansheng. 1985. Yang Hansheng riji xuan (Selections from the Diary of Yang Hansheng). Chengdu: Sichuan wenyi chubanshe. 
Yue, Daiyun, and Carolyn Wakeman. 1985. To the Storm: The Odyssey of a Revolutionary Chinese Woman. Berkeley, CA: University of California Press.

Yun, Daiying. 1981. Yun Daiying riji (Diary of Yun Daiying). Beijing: Zhonggong zhongyang dangxiao chubanshe.

Zeng, Qingjie. 2020. "Managed campaigns and bureaucratic institutions in China." Journal of Contemporary China 29(123), 400-415.

Zhang, Chengshuang. 2017. "Jingzhun fupin gongzuodui yanjiu chubu baogao" (Preliminary report on a study of precision poverty-alleviation work teams). Unpublished manuscript courtesy of author.

Zhang, Kaiyuan. 2015. Zhang Kaiyuan koushu zizhuan (Oral Autobiography of Zhang Kaiyuan). Beijing: Beijing Normal University Press.

Zhang, Yihan. 2018. "Zhucun diyi shuji xingdong luoji fenxi" (Analysing the logic of the actions of village-stationed first secretaries). Pengpai xinwen, 20 February, https://www.thepaper.cn/ newsDetail_forward_2003441.

Zhao, Dingyuan. 1952. "Shangchengxian Youfangdianxiang shenru gupinnong zhagen suku chuanlian fadong gupinnong de jige zhuyao jingyan" (Several key lessons from going deep among the hired labourers and poor peasants of Youfangdian township, Shangcheng county, by striking roots, speaking bitterness and forging connections). Zhonggong zhongyao lishi wenxian ziliao huibian 16(2), 819-820.

Zhong, Rixing (ed.). 2009. Hongqixia de xiangcun (Villages under the Red Flag). Beijing: Zhongguo shehui kexue chubanshe.

Zhou, Libo. 1955. The Hurricane. Peking: Foreign Languages Press. 